\title{
Surgical Management of Tuberculous Constrictive Pericarditis in a Developing Country: Case Report
}

\author{
Sotheenathan Krishinan ${ }^{*}$, Basheer Ahamed Abdul Kareem ${ }^{1}$, Abu Yamin Khamis ${ }^{1}$, Ahmadi Salleh', \\ Sivasangari Subramaniam², Mohd Hamzah Kamrulzaman ${ }^{1}$ \\ From World Society of Cardiothoracic Surgeons 25th Anniversary Congress, Edinburgh \\ Edinburgh, UK. 19-22 September 2015
}

\section{Background/Introduction}

Tuberculosis has been increasing in incidence in recent years especially in developing countries. Tuberculous pericarditis is a form of extra pulmonary tuberculosis that is considered unusual.

\section{Aims/Objectives}

We report a case of tuberculosis of pericardium complicated with constrictive pericarditis and the surgical challenges encountered.

\section{Method}

Diagnosis is often challenging. High indexes of suspicion combined with the use of all available diagnostic techniques are important to increase diagnostic yield. A definite or proven diagnosis is based on demonstration of tubercle bacilli in pericardial fluid or on histologic section of the pericardium. Constrictive pericarditis is a complication of tuberculous pericarditis that necessitates surgical intervention.

\section{Results}

The timing of surgical intervention is controversial, but many experts recommend a trial of medical therapy for non-calcific pericardial constriction, and pericardiectomy in non-responders after 4 to 8 weeks of anti-tuberculosis chemotherapy.

\section{Discussion/Conclusion}

Pericardiectomy is a surgical option which carries high mortality and morbidity. We report a case of tuberculosis of pericardium complicated with constrictive pericarditis and the surgical challenges both intraoperative and post operatively.

\section{Authors' details \\ ${ }^{1}$ Department of Cardiothoracic, Penang General Hospital, Georgetown, Penang, 10990, Malaysia. ${ }^{2}$ Clinical Research Center, Penang General Hospital, Georgetown, Penang, 10990, Malaysia.}

Published: 16 December 2015

doi:10.1186/1749-8090-10-S1-A186

Cite this article as: Krishinan et al:: Surgical Management of Tuberculous Constrictive Pericarditis in a Developing Country: Case Report. Journal of Cardiothoracic Surgery 2015 10(Suppl 1):A186.

'Department of Cardiothoracic, Penang General Hospital, Georgetown, Penang, 10990, Malaysia

Full list of author information is available at the end of the article

Submit your next manuscript to BioMed Central and take full advantage of:

- Convenient online submission

- Thorough peer review

- No space constraints or color figure charges

- Immediate publication on acceptance

- Inclusion in PubMed, CAS, Scopus and Google Scholar

- Research which is freely available for redistribution

Submit your manuscript at www.biomedcentral.com/submit
() Biomed Central 